\title{
COVID-19 Transmission Dynamics: A Space-and-Time Approach
}

\author{
Marta Moniz ${ }^{a, b}$ Patrícia Soares ${ }^{a, b} \quad$ Carla Nunes ${ }^{a, b}$ \\ ${ }^{a}$ NOVA National School of Public Health, Public Health Research Center, Universidade NOVA de Lisboa, Lisbon, \\ Portugal; ${ }^{b}$ Comprehensive Health Research Center, Universidade NOVA de Lisboa, Lisbon, Portugal
}

\section{Keywords}

Epidemiology · Relative risk · COVID-19 · Spatial distribution · Transmission dynamics

\begin{abstract}
Background: At the end of January 2021, Portugal had over 700,000 confirmed COVID-19 cases. The burden of COVID-19 varies between and within countries due to differences in contextual and individual factors, transmission rates, and clinical and public health interventions. Objectives: To identify high-risk areas, between April and October, on a weekly basis and at the municipality level, and to assess the temporal evolution of COVID-19, considering municipalities classified by incidence levels. Methods: This is an ecological study following a 3-step approach, i.e., (1) calculation of the relative risk (RR) of the number of new confirmed COVID-19 cases, weekly, per municipality, using a spatial scan analysis; (2) classification of the municipalities according to the European Centre for Disease Control incidence categorization on November 19; and (3) characterization of RR temporal evolution by incidence groups. Results: Between April and October, the mean RR was 0.53 , with a SD of 1.44 , varying between 0 and 46.4. Globally, the north and Lisbon and Tagus Valley (LVT) area were the regions with the highest number of municipalities with a RR above 3.2. In April and beginning of May, most of the municipalities with an RR above 3.2 were from the north, while between May and August most mu-
\end{abstract}

nicipalities with an RR above 3.2 were from LVT area. Comparing the incidence in November and retrospectively analyzing the RR showed the huge variation, with municipalities with an RR of 0 at a certain time classified as extremely high in November. Conclusions: Our results showed considerable variation in RR over time and space, with no consistent "better" or "worst" municipality. In addition to the several factors that influence COVID-19 transmission dynamics, there were some outbreaks over time and throughout the country and this may contribute to explaining the observed variation. Over time, on a weekly basis, it is important to identify critical areas allowing tailored and timely interventions in order to control outbreaks in early stages.

(c) 2021 The Author(s). Published by S. Karger AG, Basel on behalf of NOVA National School of Public Health

\section{Dinâmicas de transmissão da COVID-19: uma abordagem no espaço e no tempo}

\section{Palavras Chave}

Epidemiologia · Risco relativo · COVID-19 - Distribuição espacial $\cdot$ Dinâmicas de transmissão

\section{Resumo}

Introdução: No final de Janeiro de 2021, Portugal tinha mais de 700 mil casos de COVID-19 notificados. O peso da (c) 2021 The Author(s). Published by S. Karger AG, Basel on behalf of NOVA National School of Public Health

This is an Open Access article licensed under the Creative Commons Attribution-NonCommercial-4.0 International License (CC BY-NC) (http://www.karger.com/Services/OpenAccessLicense), applicable to the online version of the article only. Usage and distribution for commercial purposes requires written permission.
Correspondence to:

Marta Moniz,am.moniz@ensp.unl.pt 
COVID-19 varia entre países e a nível nacional devido a diferentes fatores individuais e contextuais, taxas de transmissão e diferentes intervenções clínicas e de saúde pública. Objetivos: Identificar áreas de maior risco, semanalmente, ao nível dos municípios, entre Abril e Outubro, e a sua variação ao longo do tempo, considerando a classificação, por níveis de incidência, dos municípios. Métodos: Estudo ecológico com uma abordagem em 3 fases: (1) Cálculo do risco relativo (RR) do número de novos casos de COVID-19 notificados semanalmente, por município, utilizando metodologia de análise espacial; (2) Classificação dos municípios de acordo com a categorização de incidência do Centro Europeu para o Controlo de Doenças (ECDC) a 19 de Novembro; (3) Caracterização da evolução temporal do RR por grupos de incidência. Resultados: Entre Abril e Outubro, a média dos RR foi $0.53 \mathrm{com}$ um desvio padrão de 1.44, variando entre 0 e 46.4. Globalmente, o Norte e a área de Lisboa e Vale do Tejo (LVT) foram as regiões com um maior número de municípios com RR acima de 3.2. Em Abril e no início de Maio, a maioria dos municípios com RR acima de 3.2 eram do Norte, enquanto entre Maio e Agosto, a maioria dos municípios com RR acima de 3.2 eram da área de LVT. Comparando a incidência em Novembro e, analisando retrospetivamente, os RR apresentaram uma grande variação, existindo municípios, num determinado momento, com RR de 0 , classificados como extremamente elevados, em Novembro. Conclusões: Os riscos relativos apresentaram uma variação considerável ao longo do período de tempo e espaço analisados. Nenhum município apresentou valores consistentemente "melhores" ou "piores." AdicionaImente aos vários fatores que influenciam a dinâmica de transmissão da COVID-19, a existência de vários surtos que foram ocorrendo ao longo de todo o território nacional, pode também ajudar a explicar a variação observada. A identificação semanal de áreas críticas é importante, pois possibilita a implementação de intervenções atempadas permitindo um controlo controlar os surtos em fases iniciais.

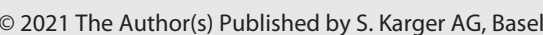
on behalf of NOVA National School of Public Health

\section{Introduction}

COVID-19 was first reported in China at the end of 2019. On January 30, the World Health Organization declared COVID-19 a Public Health Emergency of International Concern, and on March 11 it was declared a pandemic [1]. The first case in Portugal was reported on March 2n and by the end of January 2021 Portugal had almost 700,000 confirmed cases and 12,000 deaths [2].

The burden of COVID-19 varies between and within countries $[3,4]$ due to differences in contextual and individual factors, transmission rates, and clinical and public health interventions [5]. The rapid evolution and variation of COVID-19 are influenced by its transmission dynamics, which can be described as its diffusibility [6]. The transmission from infectious to susceptible hosts depends on contact rates among individuals and the probability that contacts result in transmission $[6,7]$. This is an important concept in disease control as it tries to describe the disease's pattern and how the implementation of public health measures can contain its spread [8], reducing the number of contacts and thus reducing the transmission rate [9].

It is therefore importance to describe the geographic distribution of COVID-19 incidence to control outbreaks and to develop public health policies. During an emerging infectious disease like COVID-19, it is critical to implement space-time surveillance to prioritize targeted interventions, rapid testing, and resource allocation. Relative risk (RR) analysis has been widely used to describe and monitor COVID-19 time and space variation within countries, not only prospectively but also retrospectively, in order to describe spatial patterns $[3,4,10]$. Hence, the aim of this study is to identify high-risk areas, between April and October, on a weekly basis and at the municipality level, and to assess its temporal evolution, considering municipalities classified by incidence levels.

\section{Methods}

This ecologic study follows a 3-step approach, i.e., (1) calculation of the RR based on the number of new COVID-19 cases notified per municipality on a weekly basis, (2) classification of the municipalities according to the European Centre for Disease Control (ECDC) incidence categorization on November 19, and (3) characterization of RR temporal evolution by incidence groups (defined in step 2).

Data on COVID-19 cases per municipality, and classified according to the ECDC incidence categorization, were downloaded from the Portugal Directorate General of Health (DGS) website, dedicated to COVID-19 [11]. The population by municipality was downloaded from Statistics Portugal (INE) [12].

For the first step of the analysis, we calculated the weekly number of new confirmed COVID-19 cases between April 4 and October 26, 2020, for each municipality. The dependent variable corresponded to the weekly number of new confirmed COVID-19 cases divided by the population in each municipality. This methodology was proposed by Kulldorff and Nagarwalla [13] and tests the existence of significant spatial disease clusters. Each analysis results in an RR for each municipality, which can be higher than 1 , 1 , or lower than 1 . For example, an RR equal to 1.2 for a given area 


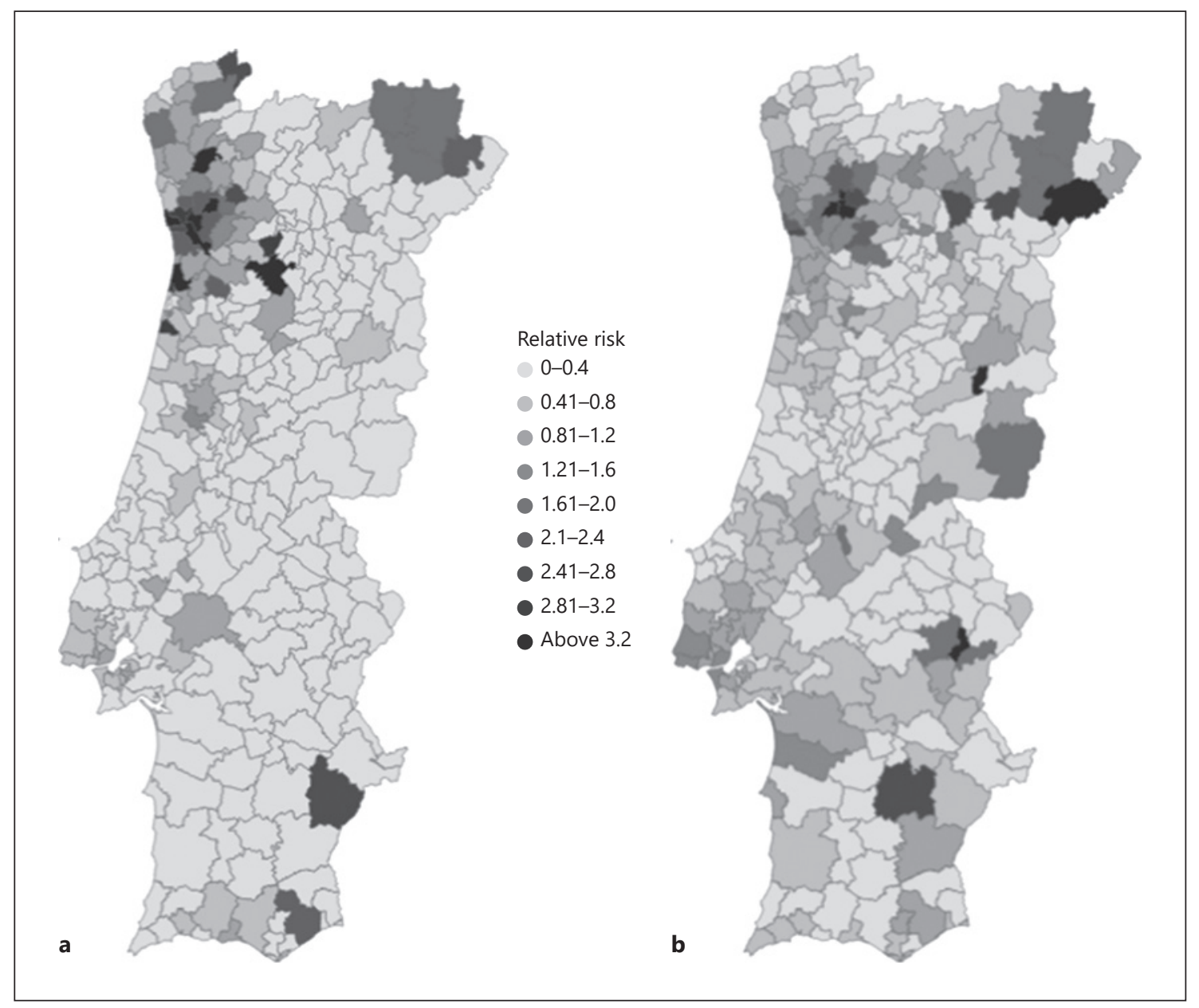

Fig. 1. RR of new COVID-19 cases notified for each municipality. Islands are not shown. a RR of new COVID-19 cases confirmed between April 4 and 10. b RR of new COVID-19 cases notified between October 19 and 26.

translates into a $20 \%$ increased risk of a higher incidence of cases in that specific area compared with the rest of the country. To map $\mathrm{RR}$ the following rationale were used: (1) an initial class centered around 1 (RR reference value), adding 0.2 to the inferior and superior limit, creating a class $0.81-1.2$, and (2) the 0.4 interval was applied to define 8 other intervals, with the first interval being between 0.0 and 0.4 and the last interval above 3.2. The geographical units were Portuguese municipalities $(n=308)$. SaTScan ${ }^{\mathrm{TM}}$ software was used, and circular window shapes and isotonic spatial scan statistics were applied [14].

For the second step of this study, we used the 14-day cumulative incidence by municipality on November 19, corresponding to the cumulative incidence between November 6 and 19, 2020. Before this date, the numbers of COVID-19 cases per municipality were available on a weekly basis, but on November 19 the DGS started to release only the 14-day cumulative incidence (based on the ECDC criteria). The incidence was categorized according to the ECDC incidence classification (per 100 thousand inhabitants) as follows: low, < 120; moderate, between 120 and 239.9; high, between 240 and 479.9; very high, between 480 and 959.9; and extremely high, $>960$.
In the third step, we grouped the municipalities according to the 14-day cumulative incidence on November 19 (low, moderate, high, very high, and extremely high) and described the RR by month per municipality using measures of central tendency, i.e., mean and median, and measures of dispersion, i.e., SD. The descriptive analysis was performed using R 4.0.2 [15].

\section{Results}

RR were calculated weekly for each municipality. Figure 1a shows the RR of new COVID-19 cases confirmed between April 4 and 10 for each municipality, while Figure $1 \mathrm{~b}$ shows the RR between October 19 and 26 (the first and last weeks under study). At the beginning of April, the Northern Portuguese coast had more municipalities with higher RR than the rest of the country. By the end of October, the highest RR could be seen in Northeastern 


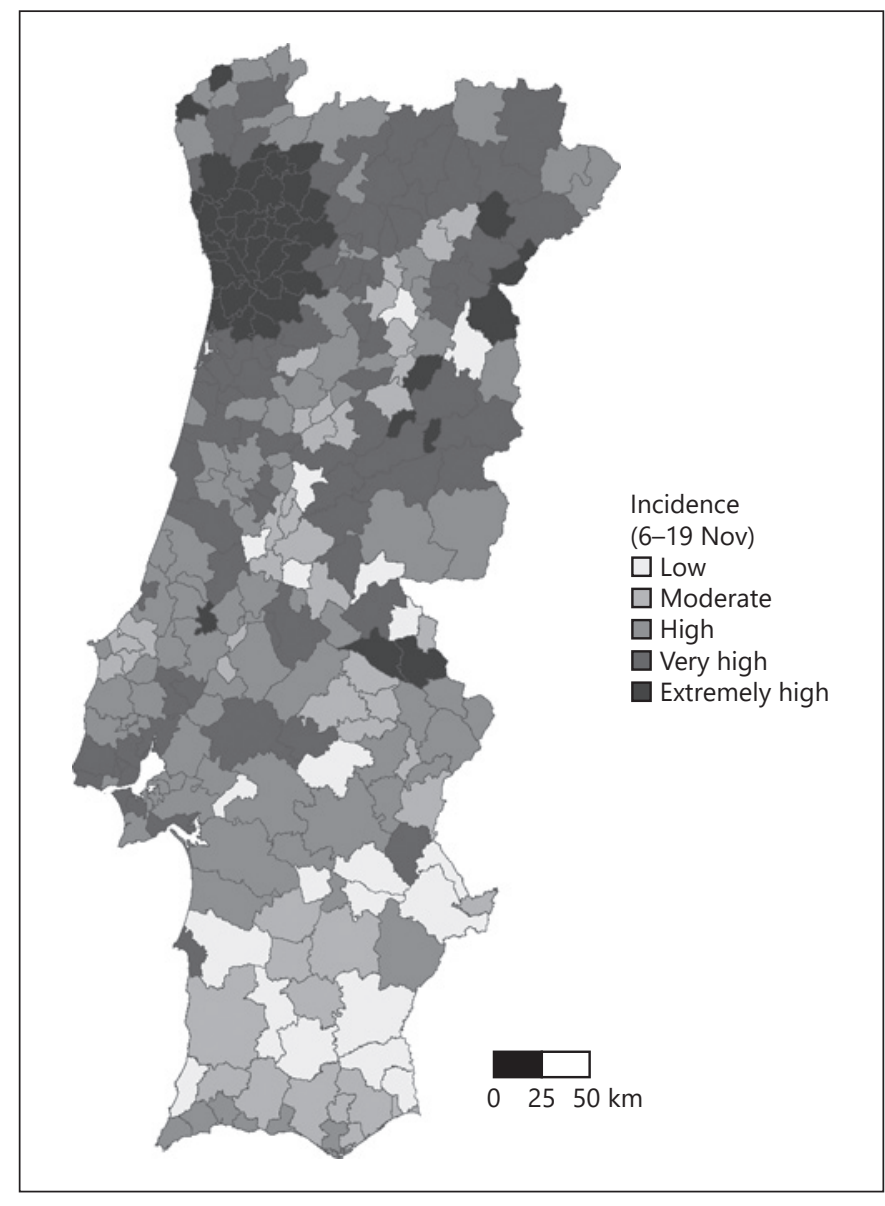

Fig. 2. Fourteen-day cumulative incidence of COVID-19 cases, according to the ECDC classification. Islands are not shown. Low, $<120$; moderate, between 120 and 239.9; high, between 240 and 479.9; very high, 480 and 959.9; and extremely high, $>960$.

Portugal. During both instances, different municipalities were identified in the South of Portugal.

The global mean RR was 0.53 , with an SD of 1.44 , varying between 0 (minimum) and 46.4 (maximum). The highest class created included RR above 3.2, corresponding to areas where the risk of having more cases was at least 3.2 higher than the rest of the country. These high critical areas were analyzed over time, and several municipalities were identified between April and October. The north and the Lisbon and Tagus Valley (LVT) area were the regions with a higher number of these high RR. In April and the beginning of May, most of the high critical municipalities were in the north region, while between May and August most of them were in the LVT area. In fact, Amadora, Sintra, Loures, and Odivelas, municipalities from the LVT area, were consistently identified with an RR above 3.2 between May
15 and July 31 . In the middle of August, the highest RR was once again spotted in the north region. Over time, several municipalities with extremely high RR were associated with outbreaks, such as Reguengos de Monsaraz in June $(R R=43.9)$, Azambuja in May $(R R=5.8)$, Bombarral in June $(R R=4.6)$, Lagos in June $(R R=6.4)$, and Vimioso in September $(R R=22.9)$; most of them were in relatively small municipalities (in terms of population).

We then classified the municipalities according to the 14-day cumulative incidence on November 19 as low, moderate, high, very high, or extremely high. Figure 2 shows the incidence category for each municipality. The mean RR was calculated for each month, globally, and each incidence category (Table 1).

Overall, the mean RR presented by month was low (between 0.38 and 0.65 ), while the maximum ranged from 9.3 to 46.4, corresponding to Miranda do Douro and Mora, respectively. For the low incidence category, the median RR was 0 for each month, while for the extremely high incidence category the median RR ranged from 0 in June to 1.13 in April. June was consistently the month with the lowest RR across the different categories, except for the very high and moderate incidence categories. August was the month with the lowest RR for the very high category, while for the moderate incidence category May was the month with the lowest RR. Contrarily, the highest RR was found in September for the low and high incidence categories, while for the moderate and very high incidence categories the highest RR was found in August. The extremely high incidence category had the highest RR in April. The categories extremely high, very high, and high showed the largest variation throughout the months, as shown in Figure 3.

\section{Discussion/Conclusion}

The main goal of this study was to identify high-risk areas at the municipality level and assess the temporal evolution of COVID-19, demonstrating the high variability of this disease through space and time. Our results showed considerable variation in RR over time, with no consistent "better" or "worst" municipalities. The comparison of the incidence in November and the retrospective analysis of the RR showed a substantial variation, with municipalities with an RR of 0 classified as extremely high incidence areas and municipalities with an RR equal to 25 classified as low incidence. No clear patterns were differencing the distinct incidence categorization 
Table 1. Mean monthly RR considering the municipality classification based on the 14-day cumulative incidence on November 19

\begin{tabular}{|c|c|c|c|c|c|c|}
\hline \multirow{2}{*}{$\begin{array}{l}\text { Incidence (municipalities, } n \text { ) } \\
\text { Global (308) }\end{array}$} & \multirow{2}{*}{$\begin{array}{l}\text { Month } \\
\text { April }\end{array}$} & \multirow{2}{*}{$\begin{array}{l}\text { Mean } \\
0.54\end{array}$} & \multirow{2}{*}{$\begin{array}{l}\text { Median } \\
0.00\end{array}$} & \multirow{2}{*}{$\begin{array}{l}\mathrm{SD} \\
1.12\end{array}$} & \multicolumn{2}{|c|}{ Minimum Maximum } \\
\hline & & & & & 0.00 & 12.0 \\
\hline & May & 0.47 & 0.00 & 1.25 & 0.00 & 23.7 \\
\hline & June & 0.38 & 0.00 & 1.51 & 0.00 & 43.9 \\
\hline & July & 0.42 & 0.00 & 0.93 & 0.00 & 9.3 \\
\hline & August & 0.62 & 0.00 & 1.91 & 0.00 & 46.4 \\
\hline & September & 0.65 & 0.28 & 1.59 & 0.00 & 25.0 \\
\hline & October & 0.59 & 0.33 & 0.92 & 0.00 & 10.9 \\
\hline \multirow[t]{7}{*}{ Low (46) } & April & 0.20 & 0.00 & 0.83 & 0.00 & 6.89 \\
\hline & May & 0.21 & 0.00 & 1.44 & 0.00 & 17.89 \\
\hline & June & 0.07 & 0.00 & 0.50 & 0.00 & 6.19 \\
\hline & July & 0.20 & 0.00 & 0.81 & 0.00 & 6.50 \\
\hline & August & 0.21 & 0.00 & 0.91 & 0.00 & 8.37 \\
\hline & September & 0.48 & 0.00 & 2.56 & 0.00 & 25.02 \\
\hline & October & 0.27 & 0.00 & 0.74 & 0.00 & 5.63 \\
\hline \multirow[t]{7}{*}{ Moderate (49) } & April & 0.19 & 0.00 & 0.60 & 0.00 & 5.37 \\
\hline & May & 0.14 & 0.00 & 0.42 & 0.00 & 2.73 \\
\hline & June & 0.22 & 0.00 & 0.78 & 0.00 & 5.67 \\
\hline & July & 0.22 & 0.00 & 0.50 & 0.00 & 2.74 \\
\hline & August & 0.49 & 0.00 & 1.51 & 0.00 & 14.63 \\
\hline & September & 0.35 & 0.00 & 0.71 & 0.00 & 5.49 \\
\hline & October & 0.33 & 0.15 & 0.59 & 0.00 & 3.74 \\
\hline \multirow[t]{7}{*}{ High (87) } & April & 0.43 & 0.00 & 1.20 & 0.00 & 11.97 \\
\hline & May & 0.48 & 0.00 & 1.48 & 0.00 & 23.70 \\
\hline & June & 0.39 & 0.00 & 0.79 & 0.00 & 6.39 \\
\hline & July & 0.58 & 0.00 & 1.13 & 0.00 & 9.33 \\
\hline & August & 0.66 & 0.08 & 1.23 & 0.00 & 9.45 \\
\hline & September & 0.70 & 0.39 & 1.53 & 0.00 & 22.89 \\
\hline & October & 0.54 & 0.41 & 0.80 & 0.00 & 10.57 \\
\hline \multirow[t]{7}{*}{ Very high (79) } & April & 0.49 & 0.22 & 0.81 & 0.00 & 5.67 \\
\hline & May & 0.63 & 0.00 & 1.16 & 0.00 & 6.71 \\
\hline & June & 0.72 & 0.00 & 2.57 & 0.00 & 43.87 \\
\hline & July & 0.57 & 0.00 & 1.11 & 0.00 & 4.87 \\
\hline & August & 0.87 & 0.10 & 3.13 & 0.00 & 46.38 \\
\hline & September & 0.62 & 0.31 & 0.76 & 0.00 & 3.90 \\
\hline & October & 0.64 & 0.39 & 0.83 & 0.00 & 7.80 \\
\hline \multirow[t]{7}{*}{ Extremely high (47) } & April & 1.52 & 1.13 & 1.49 & 0.00 & 9.14 \\
\hline & May & 0.81 & 0.46 & 1.18 & 0.00 & 7.88 \\
\hline & June & 0.26 & 0.00 & 1.20 & 0.00 & 17.12 \\
\hline & July & 0.28 & 0.14 & 0.48 & 0.00 & 2.95 \\
\hline & August & 0.67 & 0.34 & 1.15 & 0.00 & 7.62 \\
\hline & September & 1.09 & 0.67 & 2.00 & 0.00 & 21.65 \\
\hline & October & 1.20 & 0.93 & 1.35 & 0.00 & 10.88 \\
\hline
\end{tabular}

classes, highlighting the importance of these analyses continuously in space and time.

RR was analyzed weekly, allowing identification of the "worst" ( RR > 1) municipalities in each week. This analysis shows the RR compared with the remaining municipalities and is highly susceptible to outbreaks. However, one should be aware that RR are not similar to incidence. $\mathrm{RR}$ are comparative measures, comparing the risk inside one municipality with the risk of the rest of the country.

Several factors influence the transmission dynamics of infectious disease, and COVID-19 is no exception. As some authors explain, the dynamics of infectious diseases 
Fig. 3. Variation of the mean RR by month according to the 14-day cumulative incidence classification (on November 19).

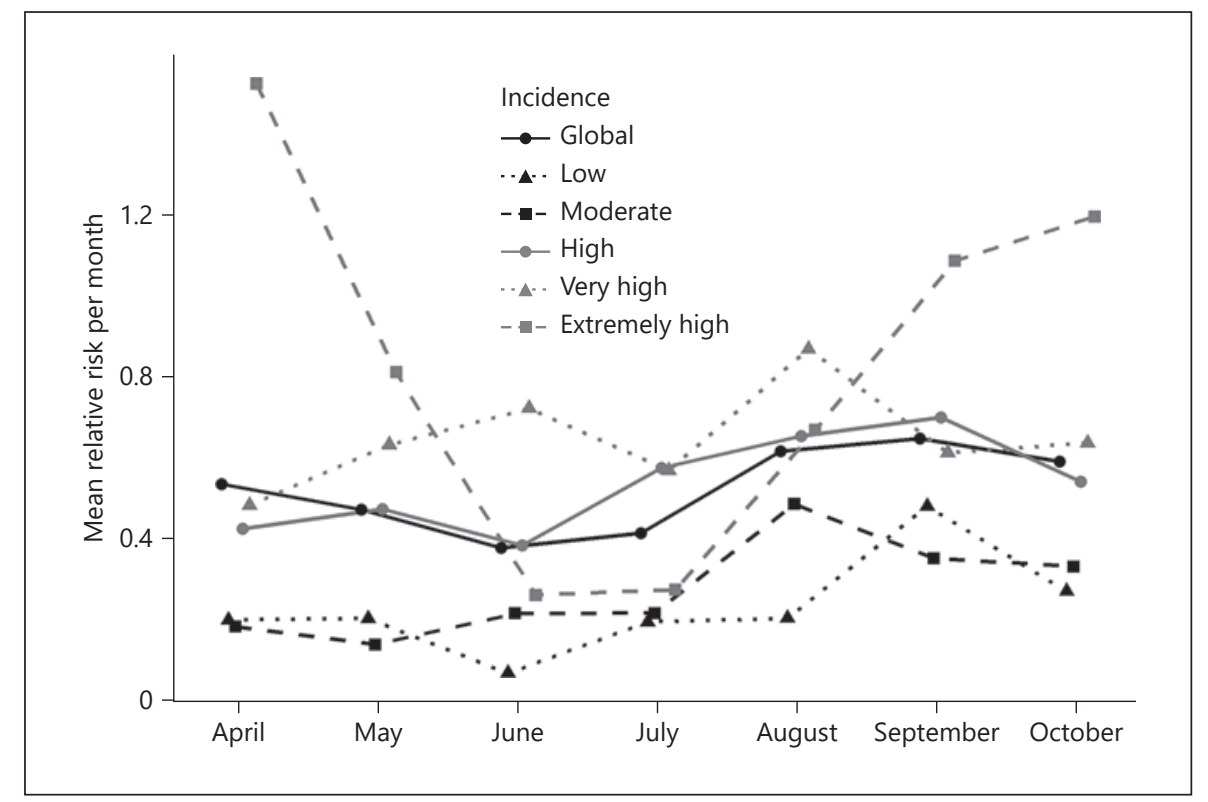

are influenced by person-to-person interactions, geographical distributions, contextual factors, lengths of latency, and humans' heterogeneous nature $[16,17]$. COVID-19 emerged as a new disease in 2020, making case identification more complicated either because of the unknown duration of the infectious period or the unknown period to develop more severe symptoms. Due to unknown COVID-19 infectious mechanisms, and to a decrease in the reproduction ratio, massive public health interventions, such as lockdowns, hygiene measures, closing schools, and extensive travel restrictions were put in place internationally [18]. In some diseases, the geographical variation can be explained by common contextual factors, such as socioeconomic differences and individual factors. However, for COVID-19, the differences cannot be explained solely by those factors.

Throughout the pandemic, several outbreaks were identified in specific settings, such as nursing homes [19, 20], factories [21, 22], or even after illegal parties [23], which may explain why some areas peaked in a given period. However, when an outbreak spreads beyond its initial setting or its origin is unclear, control might be more difficult and take longer to achieve. If not controlled in due time, the outbreak can spread to other locations. Therefore, detailed identification of critical areas, in time and space, allows the implementation of timely interventions to control the spread of the pandemic.

The spatial variation might also be explained by public health interventions implemented over time, as these included specific tailored interventions for each municipal- ity, according to the municipality incidence. Public health interventions aim to reduce transmission rates, influencing several factors involved in transmission dynamics, such as population mobility. Overall, the mean monthly RR during June, July, and August were below 1 for most municipalities, which might be explained by behavioral changes during the holidays. In summer, there was a loosening of the measures implemented in previous months. This decrease might be due to the impact of previous lockdowns, which were still noticeable and might have been perceived as positive progress, leading to a false sense of security. On the other hand, individuals were more often outside, in open spaces, schools were closed, and individuals may have chosen to travel to isolated locations for holidays. The first lockdown, in Portugal, had a substantial impact on reduction of the number of cases, hospital admissions, and deaths during the first wave [9]. However, lockdowns should be the last resort, as these have a strong economic and social impact, and thus they should not be used constantly and/or for a long period of time. Gradually, these measures were loosened over time and adapted according to the municipality incidence. One should be aware that for every public health intervention implemented the natural transmission pattern is altered, which is often the aim. However, governments and populations should understand that returning to a normal life will take some time and be prepared for the implementation of future lockdowns if needed.

This is an ecological study and has some limitations associated. The data used depend directly on notification 
rates, considering only already diagnosed cases. In the present study, it is also assumed that, despite the identified biases, the risk variation phenomenon is consistent across the country, varying in space and time.

\section{Acknowledgement}

The authors would like to thank the DGS and INE for their publicly available data and for allowing it to be used for research purposes.

\section{Conflict of Interest Statement}

The authors have no conflict of interests to declare.

\section{Funding Sources}

This study was funded by the Foundation for Science and Technology through the $\mathrm{PhD}$ research scholarship (2020.09525.BD) granted under the Call DOCTORATES 4 COVID-19.

\section{Author Contributions}

C.N. concept and design; M.M. and P.S. acquisition, analysis, or interpretation of data; M.M., P.S., and C.N. drafting of the manuscript; M.M., P.S., and C.N. critical revision of the manuscript for important intellectual content; P.S. statistical analysis; C.N. supervision.

\section{References}

1 World Health Organization. WHO DirectorGeneral's opening remarks at the media briefing on COVID-19: 11 March 2020 [Internet]. 2020 [cited 2020 Nov 30]. Available from: https://www.who.int/dg/speeches/detail/ who-director-general-s-opening-remarks-atthe - media - briefing-on-covid19--11-march-2020.

2 European Centre for Disease Prevention and Control. Geographic distribution of COVID-19 cases worldwide [Internet]. 2020 [cited 2021 Jan 25]. Available from: https://www. ecdc.europa.eu/en/publications-data/download-todays-data-geographic-distributioncovid-19-cases-worldwide.

3 Desjardins MR, Hohl A, Delmelle EM. Rapid surveillance of COVID-19 in the United States using a prospective space-time scan statistic: detecting and evaluating emerging clusters. Appl Geogr. 2020 May;118:102202.

4 Ballesteros P, Salazar E, Sánchez D, Bolanos C. Spatial and spatiotemporal clustering of the COVID-19 pandemic in Ecuador. Rev Fac Med (Caracas). 2020;69(1):1-8.

5 Liu T, Liang W, Zhong H, He J, Chen Z, He $\mathrm{G}$, et al. Risk factors associated with $\mathrm{CO}$ VID-19 infection: a retrospective cohort study based on contacts tracing. Emerg Microbes Infect. 2020 Dec;9(1):1546-53.

6 Barreto ML, Teixeira MG, Carmo EH. Infectious diseases epidemiology. J Epidemiol Community Health. 2006 Mar;60(3):192-5.

7 Real LA, Biek R. Infectious disease modeling and the dynamics of transmission. In: Childs JE, Mackenzie JS, Richt JA, editors. Wildlife and emerging zoonotic diseases: the biology, circumstances and consequences of crossspecies transmission [Internet]Berlin, Heidelberg: Springer Berlin Heidelberg; 2007. pp. 33-49.
8 Wendelboe AM, Grafe C, Carabin H. The benefits of transmission dynamics models in understanding emerging infectious diseases. Am J Med Sci. 2010 Sep;340(3):181-6.

9 Ricoca Peixoto V, Vieira A, Aguiar P, Carvalho C, Rhys Thomas D, Abrantes A. Initial assessment of the impact of the emergency state lockdown measures on the 1st wave of the COVID-19 epidemic in Portugal. Acta Med Port. 2020 Nov;33(11):733-41.

10 Alkhamis MA, Al Youha S, Khajah MM, Ben Haider N, Alhardan S, Nabeel A, et al. Spatiotemporal dynamics of the COVID-19 pandemic in the State of Kuwait. Int J Infect Dis. 2020 Sep;98:153-60

11 Ministério da Saúde (Portugal). COVID-19: relatório de situação - 19 novembro 2020. Lisboa: DGS; 2020.

12 Instituto Nacional de Estatística. Especial INE Covid-19. [Internet]. Lisboa: INE; 2020 [cited $2021 \mathrm{Feb} 2]$. Available from: https://www.ine. pt/xportal/xmain? xpgid=ine main\&xpid=INE

13 Kulldorff M, Nagarwalla N. Spatial disease clusters: detection and inference. Stat Med. 1995 Apr;14(8):799-810.

14 Harvard Medical School, Harvard Pilgrim Health Care Institute. SaTScanTM v8.0: software for the spatial and space-time scan statistics [Internet]. Boston: Department of Population Medicine; 2009. Available from: http://www.satscan.org.

$15 \mathrm{R}$ Core Team. R: a language and environment for statistical computing [Internet]. Vienna: R Foundation for Statistical Computing; 2018. Available from: https://www.R-project.org/.

16 Erraguntla M, Zapletal J, Lawley M. Framework for Infectious Disease Analysis: A comprehensive and integrative multi-modeling approach to disease prediction and management. Health Informatics J. 2019 Dec;25(4):1170-87.
17 Kucharski AJ, Russell TW, Diamond C, Liu Y, Edmunds J, Funk S, et al.; Centre for Mathematical Modelling of Infectious Diseases COVID-19 working group. Early dynamics of transmission and control of COVID-19: a mathematical modelling study. Lancet Infect Dis. 2020 May;20(5):553-8.

18 Mitchison NA. Mathematical models in immunology. Nature. 1978;275(5681):675-6.

19 Lusa. Covid-19: lar de Reguengos de Monsaraz corrige questões detectadas em vistoria [Internet]. 2020 [cited $2021 \mathrm{Feb} 3$ ]. Available from: https://www.publico.pt/2020/09/07/ sociedade/noticia/covid19-lar-reguengosmonsaraz-corrige-questoes-detectadas-vistoria-1930717.

20 RTP. Surto de Covid-19 fez segunda vítima mortal em lar de Vimioso [Internet]. 2020 [cited 2021 Feb 3]. Available from: https:// www.rtp.pt/noticias/pais/surto-de-covid19-fez-segunda-vitima-mortal-em-lar-de-vimioso_v1260369.

21 Talixa J, Henrique A. Covid-19: foco na Azambuja é um dos mais preocupantes na região de Lisboa [Internet]. 2020 [cited 2021 Feb 3]. Available from: https://www.publico. pt/2020/05/21/local/noticia/foco-azambujapreocupantes-regiao-lisboa-1917565.

22 RTP. Covid-19. Preocupações com foco de infeções no Bombarral [Internet]. 2020 [cited $2021 \mathrm{Feb} 3]$. Available from: https://www.rtp. pt/noticias/pais/covid-19-preocupacoescom-o-foco-do-bombarral_v1234620.

23 Gonçalves M, Chaíça I; Lusa. Covid-19: perto de "uma centena de pessoas" passou por festa em Lagos: há pelo menos 16 infectados [Internet]. 2020 [cited $2021 \mathrm{Feb} 3$ ]. Available from: https://www.publico.pt/2020/06/16/sociedade/noticia/covid19-registados-nove-casospositivos-relacionados-festa-ilegal-lagos-1920719. 